\title{
THE COLLATERAL DAMAGE OF INFORMAL LEARNING, CREATION OF IDENTITY THROUGH THE MEDIA
}

\begin{abstract}
The identity development between the individual and society, its connection with the informal learning in the Web 2.0 and Web 3.0 environment and its consequences on the individual as a part of a possible opinion making and changing community are being discussed in this paper. Analyzing the difference between informal learning from the traditional one way media and the newer two way media through an actual example in Slovenia raises and tries to find possible indications to the question, what the consequences, the collateral damage of informal learning, creation of identity through media, especially regarding lying, corruption and clientelism, might be.
\end{abstract}

Key words: identity, informal learning, new media, traditional media, Web 2.0, Web 3.0.

\section{Introduction}

Modern usage, findings and meaning of the term identity are nowadays well spread as well in everyday life as in science. It seems that on one hand the term became a useful manipulation tool for justifying the small powerless men to a higher, from his point sometimes even untrustful system and at the same time an opportunity for this small powerless men to avoid, even escape the reality. This reality in the last decade extended the borders into the World Wide Web, a place, where time, social roles and all that determines an individual in the real world, which are, paradoxically, the same things that make him subordinate to the greater system above him, in the unreal world become unimportant. There he has the opportunity to become a multiple personal subject, his (non) pedigreeic cards got mixed up all over again as many times he wants and chooses, it is a place where his history gathered experiences can be erased or at least forgotten.

The border between the online, electronic dimension of life and of the real life are getting more and more blurry, which expressingful indicates a case in the United Kingdom, where a man and a woman fell in love through their avatars in the virtual world Second Life. They got married in real life, but not so far after the wedding the wife caught the avatar of her husband cheating on her in Second Life. As she filed in the divorce (in real life) an English judged accepted it as a proper reason, which means, that the online world got (iuristicly) authorised in the real world. Furthermore, it indicates that the online world, relations and happenings (can) get evaluated as same as the real world ones. It is a significant step that is accepting the variety of possible, new, by each owner costumed identities as real, a step back from a traditional connotations of the subjects traditionally formed identity turns him into multiple potential changing, but still - sui generis. 
PROBLEMS

OF EDUCATION

IN THE $21^{\text {st }}$ CENTURY

Volume 46, 2012

\section{Identity (between the individual and society)}

It were the postmodernists who focused on the theoretical devotion on identity. Ule Nastran (2001) says, that identity has a high potential to diagnose time, it is a never ending process, within the subject over and over modelizes himself. Identity gathered significant role in policy and media discussions, it summarizes the differences and similarities and is not build on morality, but on conscious intensions, decisions and points of view. Inherited models, believes Ule Nastran, destroy the modern, new ones, which extremely differ from the traditional ones. The new models need everyday general reflection of the individuals acting, regarding the new information he gathers. "Identity as a minimal, chaotic, necessary social institution, defines the individual as a competent social actor. It is the point of intersection of the individual and the social, subjectivity and objectivity in and on the individual." (Ule Nastran, 2001, p. 322).

The meaning of the society, the great Other, considered also Mead. He believes that in order to get to know ourselves we need others. Mead (Jarvis, 2006) argues, that human thinking, experiences and acting are actually the one from society, believing in taking over the roles of others the individual considers himself in the role of the person, with whom he is interacting, which is how Meads proves that the individual with taking over roles defines and creates the self concept. He divides the self on the social (me) and the individual part (I), whereby Mead is absolutely sure that the self is not inherited but learned, similar as the meanings of symbols are learned to have a sense in our society.

\section{Informal Learning and the Potential of Identity Otherness}

Identity is causing a problem through the whole modern time, writes Volčič (2008), who believes, that if the modern "problem" of identity was how to build a stable identity, the postmodern "problem" of identity is how to avoid the fix identity in order to keep open chances.

Disagreeing with Volčič can be led to another direction, the concept Web 2.0, a more personalized version, known as the second generation of World Wide Web, which between the users encourages companionship, connecting and sharing ideas, knowledge and opinions through blogs, forums, wikis, tagging and social network such as Facebook and Twitter. The concept behind Web 2.0 is not only about socializing, it is also about identity choice, creativeness and development connected with informal learning.

This type of informal learning moves the borders between passive learning from publications into active ones, find Jokisal and Riu (2010), it is about exchanging roles and terms who teaches whom, the providers and consumers of teaching material constantly (ex) change, therefore learning becomes individual creation of knowledge. At 2006 Time magazine in his annual choice of the person of the year chose "you", which symbolized the crucial meaning of people, their connections, the online promoting of what is really important for them and the important role of modern technology.

People learn the most of other people, Yasari and Karadenizi (2011) cite Cross. A research from Canada shows, that adult Canadians spent 15 hours weekly for informal learning. The internet and its online world became not only an admired tool for socialization but also the leading media for informal learning. Conner, further cite Yasari in Karadenizi, indicates, that informal learning, which is a lifelong process, consists of the skills, knowledge and attitudes that people gain by mostly social interactions in their daily lives, or the interactions with mass media, or library.

In times of internet and mobile phones (with internet access), says Drotner (2008), the formal educations in schools do not have the learning process monopoly anymore, the informal learning as a democratic tool, especially because of its possibility and the general urge of social 
inclusion, is strongly supported (also) by UNESCO. With this type of informal learning, believes Drotner, are social practices more and more defined as learning processes, furthermore, even the aspects of identity are evaluates as competence potentials.

\section{(In) Formal Learning through (Traditional) Media}

Volčič in her book Media and Identity (2008) cites Gerbner's cultivation theory, which insures the effect of (one way, traditional) media, such as radio, television and printed newspaper on the sociological construction of reality by cultivating values and views. By the classical marxists, continues Volčič, media is considered as a production tool, where class identity is the key to the dominant structure of stakeholders. The author illustrates the (formal) power of (traditional) media through a story about the mission of the most influential propaganda "tool" in Miloševič's Serbia: the national Serbian television RTVS at the time, where it had $60 \%$ viewers of the Serbian population and only $2 \%$ of them were reading the daily newspapers. Like a radio journalist from Niš in a research interview explained to Volčič, in the eighties and nineties the content of the leading information programme Dnevnik 2 was so strictly overviewed, that it needed everyday (again and again) the permission of the Serbian government.

Today, in the countries that do not reduce the online information possibilities, it seems, that the Serbian situation as described by the radio journalist could not have the same effect as an (leaded and leading) opinion maker. Similar as nowadays the informal learning, agree Jokisalo and Riu (2010), no doubtful comes before formal learning, the author of this paper evaluates, also the critical view on the final truth in the traditional one way media, followed by mass media opinion exchange precede final believe into the traditional media. Because of the wide variety of traditional and mass media, the variety of informal learning sources enable easier goals in the direction of Mezirow's believe, as Elias and Meriam (2005) quote, that the goals of andragogical learning need to help to reach self-guidance and self-reflection, and help the learner to find communities, where this qualities will be valued. It is believed that such communities can be easily found within the Web 2.0 concept, which is one of the reasons of agreeing with Hager and Halliday (2009) on the fact, that informal learning deserves greater attention. A remark is being added to the possibility, that such communities can also in extreme circumstances get dangerous, for instance in the case right winged nationalistic groups.

However, postmodernists decrease the authority of the author and increase the authority of the reader's interpretation, argue Elias and Meriam (2005), whereby they believe, that the reader understands more than the author intended to say. Umberto Eco surprisingly even suggested the writer should die after he has written the text. A similar rising of the text authority is the generation after Web 2.0 - Web 3.0, a semantic tool, as Yasari and Karadenizi (2011) describe it, that categorizes information with tagging, for instance online newspaper article with other information sources on the same subject, which decreases the time spent for online searching and at the same time increases the time spend on understanding (and, we add, developing critical views, shape the identity).

\section{Instead of Conclusion: Some Further Remarks, Discursive Questions}

Explaining the title of this paper - The Collateral Damage of Informal Learning, Creation of Identity through the Media - will serve as the conclusion's thinking remark through a real life case, that the author of this paper is going to research in the near future. As Volčič (2008) believes, we need a stable, fix identity in order to know who we are and where we belong. Searching for new identities can be enrolled by non working, destructed systems in which the system itself cannot offer an identity reference for individuals.

In the last year Slovenian citizens through (not only traditional) media sources witnessed 
PROBLEMS

OF EDUCATION

IN THE $21^{\text {st }}$ CENTURY

Volume 46, 2012

64

some sensationalisticly presented journalistic research outcomes that exposed how politicians although they were proven lying, practising some forms of clientelism and corporativism, were not facing any consequences, even smile faced continued practicing their public work as a politician.

Since on the one hand the same media sensationalisticly compared the non sanctioned faux pass (?) of the politicians in Slovenia with the similar sanctioned (!) political cases in other countries, such as Hungary, Austria and Germany, hereby lead to great concern. On the other hand the symbolic meaning of the fact that, these politicians, wearing the uniforms of capital, reflecting their economic wealthiness, doing wrong to remain gaining the engine of consumption - money. What does that symbolize, mean for the average citizen, who not only economically owns less than the politicians who obtained in fraudem legis agere, but is also feeling the consequences of the general European politically led savings which cut into qualities (and quantities) of public live?

What does the described situation mean for the identity development of the average lower middle class Slovene? Ule Nastran (2001) claims the accommodation of identities to the consumption, wide range choice and the imitation of the environment, she, furthermore, speaks of the self-economy and solving stress situation (not enough money, even hunger?) with the help of examples known through the media. She believes that the traditional values of a generation are used only as long as they continue having an inner (lucrative economical?) logic. Mead (Jarvis, 2006) as well believes into the occasional need for the new, innovative behaving. Will the new behavioural, identification accommodation happen in Slovenia?

Salecl (1993) in her book Why We Obey the Authority argues, that citizens accommodate the authority power without even noticing it, they have the feeling that it is their free choice. On the other side Salecl (2010) in her book The Choice describes the theory of rational choice, that analyzes how individuals before acting choose the way for maximum joy, output whilst minimum sacrifice, input. In the same monography she describes the view of psycho analytics that show how individuals often act outside the rational choice theory input-output logic, they rather act contra their own good "in very weird ways", she claims. In (Per) versions of Love and Hate (2011) Salecl writes, how the subject no longer believes in normative ideals offered by the society, instead he seems himself as the inventor of his own identity, but although he has the possibility to be "his own artwork", he does not feel enough competent, free of the traditional societal norms, to do so. Although he does not believe the old authorities that describe how to live, he is constantly looking for new identification points that could regulate his horrific new freedom. Therefore the author of this paper rises the question of the possibility, the consequences of the identification point network inside the Web 2.0, maybe 3.0, and their users connected into various Communities of Practises, that share their informal gathered (and shared) knowledge, within, as Wenger (Yasari in Karadenizi, 2011) believes, we all somehow are part of? Melluci (Ayres, 2001) argues that new social movement groups, organizations generate collective identities, if so, how does the new informal learning collective identity of Slovenians looks like? What did they learn - and the most important - could the collateral damage of that informal learning, creation of identity through the media and its output be that we find convincing identification, referential points, even economical common sense in lying, corruption and clientelism (for our advance)?

In Slovenia in the last 20 years there have been many studies on (the national) youth, aged between 15 and 29 years, but none of them tried to connect the questions, mentioned in this (last part of the) paper, with young people, trying to foresee what kind of ("collateral damaged"?) society young Slovenians are developing to, which is what the author of this paper is about to research within the $\mathrm{PhD}$ thesis. The output of the research, the author of this paper believes, can be crucial, not known before information for the further (non) governmental youth development strategies in the country. 


\section{References}

Ayers, D., M. (2001). CollectiveIdentity.org: Collective Identity in Online and Offline Feminist Activist Groups. Thesis, Faculty of Virginia Polytechnic Institute and State University.

Drotner, K. (2008). Informal Learning and Digital Media. Cambridge Scholars Publishing. Retrieved 3. 5. 2012, from http://www.c-s-p.org/flyers/9781847185518-sample.pdf.

Elias, L., J., Meriam, B., S. (2005). Philosophical Foundations of Adult Education. Malabar. Krieger Publishing Company.

Hager, P., Halliday, J. (2009). Recovering Informal Learning. Wisdom, Judgement and Community. Dordrecht: Springer.

Jarvis, P. (2006). Towards a Comprehensive Theory of Human Learning. New York, London: Routledge.

Jokisalo, E., Riu, A. (2010). Informal Learning in the Era of Web 2.0. ICT and Lifelong Learning for a Creative and Innovative Europe Findings, Reflections and Proposals from the Learnovation Project. Retrieved 20. 2. 2012, from http://www.elearningeuropa.info/files/media/media19656. pdf.

Salecl, R. (1993). Zakaj ubogamo oblast? Ljubljana: Državna založba Slovenije.

Salecl, R. (2010). Izbira. Ljubljana: Mladinska knjiga Založba.

Salecl, R. (2011.) (Per) verzije ljubezni in sovraštva. Ljubljana: Mladinska knjiga Založba.

Ule Nastran, M. (2000). Sodobne identitete v vrtincu diskurzov. Ljubljana: Znanstevno in publicistično središče.

Volčič, Z. (2008). Mediji in identiteta. Maribor: Fakulteta za elektrotehniko, račinalništvo in informatiko.

Yasari, O., Karadenizi, S. (2011). The Power of Social Media in Informal Learning. Education in a Technological World: Communicating Current and Emerging Research and Technological Efforts. Retrieved 15. 4. 2012, from http://www.formatex.info/ict/book/531-538.pdf.

Advised by Laima Railienè, University of Siauliai, Lithuania

Received: May 16, 2012

Accepted: July 30, 2012

Taja Kordigel 